\title{
De WHOA als instrument voor (grensoverschrijdende) groepsherstructureringen
}

\author{
Mr.S.C.Pepels*
}

\begin{abstract}
Met de Wet homologatie onderhands akkoord (WHOA) introduceert de wetgever een nieuw instrument in de Faillissementswet: het dwangakkoord buiten surseance en faillissement. De auteur verkent in dit artikel de toepassingsmogelijkheden van de WHOA bij groepsherstructureringen, zowel in nationale als in internationale context.
\end{abstract}

\section{Inleiding}

Groepen vennootschappen: lang waren ze een ondergeschoven kindje binnen het insolventierecht. De afgelopen jaren beginnen groepen vennootschappen echter in toenemende mate in zowel nationale als internationale context een eigen plaats binnen het insolventierecht in te nemen. Terwijl een regeling voor groepsvennootschappen bij het opstellen (van de voorganger) van de Europese Insolventieverordening ${ }^{1}$ in de jaren negentig nog een brug te ver werd geacht, bevat de herziene Europese Insolventieverordening (hierna: de herziene IVO) ${ }^{2}$ uit 2015 een apart hoofdstuk met bepalingen voor 'groepen ondernemingen'. ${ }^{3}$ Ook de Duitse wetgever ${ }^{4}$ en de United Nations Commission on International Trade Law (UNCITRAL) hebben recentelijk specifieke regelingen voor insolvente groepen vennootschappen ontwikkeld. ${ }^{5}$

Deze interesse voor groepen vennootschappen in financiële malaise heeft ook de Nederlandse wetgever niet onberoerd

\footnotetext{
Mr. S.C. Pepels is associate Business Restructuring and Reorganization bij Jones Day Amsterdam en verricht als buitenpromovendus onderzoek naar het grensoverschrijdend herstructureren van groepen vennootschappen onder de herziene Insolventieverordening.

1. Verordening (EG) $1346 / 2000$ van 29 mei 2000 betreffende insolventieprocedures.

2. Verordening (EU) $2015 / 848$ van 20 mei 2015 betreffende insolventieprocedures.

3. Hoofdstuk V van de herziene IVO. Zie over hoofdstuk V bijv. J.R. Berkenbosch \& E.J. Schuurs, Herstructurering van internationale groepen ondernemingen in het licht van de nieuwe Europese insolventieverordening, in: Ph.W. Schreurs, E.L. Zetteler, E.J.R. Verwey \& R.F. Feenstra (red.), De curator en het concern, Deventer: Wolters Kluwer 2017, p. 417-434.

4. Het Gesetz zur Erleichterung der Bewältigung von Konzerninsolvenzen trad op 21 april 2018 in werking en is op verschillende plekken in de Insolvenzordnung geïmplementeerd.

5. UNCITRAL nam op 15 juli 2019 de 'Model Law on Enterprise Group Insolvency' aan, digitaal beschikbaar via https://uncitral.un.org/en/
} texts/insolvency. gelaten. Bij invoering van het wetsvoorstel homologatie onderhands akkoord (hierna: de WHOA) ${ }^{6}$ zal de Fw voor het eerst sinds haar inwerkingtreding in 1896 een specifieke regeling voor groepen in financiële problemen bevatten. De WHOA is op 5 juli 2019 door de Minister voor Rechtsbescherming aangeboden aan de Tweede Kamer. ${ }^{7}$ De verwachting is dat het wetgevingstraject in 2020 nog kan worden afgerond, waarna de WHOA in de Fw zal worden geïmplementeerd.

Kort weergegeven voorziet deze nieuwe wetgeving in een regeling waarmee een schuldenaar zijn schulden kan herstructureren door een onderhands akkoord met (een deel van) zijn schuldeisers en aandeelhouder(s). Een akkoord kan bijvoorbeeld een gedeeltelijke kwijtschelding van schulden inhouden. Indien de vereiste meerderheid (voor zover relevant, ingedeeld in verschillende stemklassen) instemt met dit akkoord, kan de rechtbank het akkoord homologeren (bevestigen), waardoor het verbindend wordt voor de betrokken schuldeisers en aandeelhouders - ook voor zover zij niet met het akkoord hebben ingestemd. De regeling is erop gericht om schuldenaren die insolvent dreigen te raken een mogelijkheid te bieden hun schulden te herstructureren en zo een faillissement te voorkomen. ${ }^{8}$ De WHOA-procedure kent twee varianten: een openbare akkoordprocedure, waaraan publiciteit wordt gegeven door inschrijving in het Insolventieregister ${ }^{9}$ en het Handelsregister, ${ }^{10}$ en een besloten akkoordprocedure, waarbij niet publiek wordt gemaakt dat een herstructureringsakkoord wordt voorbereid en waarin alle verzoeken aan de rechter in de raadkamer worden behandeld. ${ }^{11}$

\footnotetext{
6. Wijziging van de Faillissementswet in verband met de invoering van de mogelijkheid tot homologatie van een onderhands akkoord, Kamerstukken II 2018/19, 35429.

7. De eerste inhoudelijke behandeling van het wetsvoorstel vond al snel na het zomerreces plaats, op 26 september 2019.

8. Zie voor een uitgebreide uiteenzetting van de WHOA N.W.A. Tollenaar, Het Wetsvoorstel Homologatie Onderhands Akkoord onder de loep genomen, TvI 2019/32.

9. Art. 370 lid 4 ontwerp-Fw.

10. Kamerstukken II 2018/19, 35249, nr. 3 (hierna: MvT), p. 6.

11. Art. 369 lid 9 ontwerp-Fw.
} 


\section{Maandblad}

Ondernemingsrecht

\section{Groepen vennootschappen naar huidig faillissementsrecht}

Het Nederlands recht gaat uit van de zelfstandigheid van rechtspersonen. $\mathrm{Zij}$ zijn, zoals bijvoorbeeld blijkt uit artikel 2:5 BW, zelfstandige rechtssubjecten met eigen rechten en verplichtingen. ${ }^{12}$ Dit uitgangspunt komt eveneens tot uitdrukking in het Nederlandse insolventierecht. De Fw gaat uit van de individuele schuldenaar als het object van insolventieprocedures en biedt geen bijzondere bepalingen voor groepen vennootschappen. De afwikkeling van insolventieprocedures vindt in beginsel plaats op enkelvoudige basis.

Dat kan onder omstandigheden nadelige gevolgen hebben. Het separaat afwikkelen van boedels van groepsvennootschappen door verschillende curatoren kan bijvoorbeeld leiden tot informatieverlies, inefficiënt beheer van de boedels en onnodige kosten vanwege dubbel werk. De juridische enkelvoudige benadering kan bij (naderende) insolventie van de groepsvennootschappen leiden tot desintegratie van de onderneming en tot verlies van waarde, als een groep voorafgaand aan de insolventieprocedures vanuit bijvoorbeeld organisatorisch, economisch of financieel perspectief een geïntegreerde en/of gecentraliseerde onderneming dreef. ${ }^{13}$

De Nederlandse insolventierechtpraktijk heeft daarom verschillende pragmatisch ingestoken instrumenten ontwikkeld om de juridische benadering van insolvente groepen vennootschappen dichter in de buurt te brengen bij de realiteit van geïntegreerde en gecentraliseerde groepsondernemingen. Zo is in de rechtspraak een beperkte uitzondering geformuleerd op het uitgangspunt van enkelvoudige afwikkeling: geconsolideerde (ook wel: samengevoegde) afwikkeling van de boedels van meerdere vennootschappen is toegestaan indien de activa of de administratie van meerdere boedels zodanig zijn vermengd dat zij niet meer op reële basis zijn te separeren. ${ }^{14}$ De samengevoegde faillissementsboedels worden dan behandeld als waren zij één vermogen. ${ }^{15}$ Een dergelijke situatie doet zich evenwel slechts in uitzonderingsgevallen voor. Daarnaast benoemen Nederlandse rechtbanken vaak één of meer dezelfde curatoren in faillissementen van groepsentiteiten, ${ }^{16}$

12. M.L.H. Reumers, Samengevoegde afwikkeling van faillissementen, Deventer: Kluwer 2007, p. 15.

13. Zie uitgebreid over de problematiek van groepsvennootschappen in faillissement Reumers 2007, p. 15-72.

14. De Hoge Raad sanctioneerde deze praktijk reeds in 1987, in HR 25 september 1987, NJ 1988/136 (Van Kempen en Beheer/Zilfra en DCW).

15. Zie verder over geconsolideerde afwikkelingen onder meer Reumers 2007, p. 32-36 en de aldaar aangehaalde bronnen.

16. In Duitsland is de bevoegdheid tot het benoemen van één of meer dezelfde curatoren bij de herziening van de Insolvenzordnung in april 2018 zelfs verankerd in de wet, zie $\$ 56$ b InsO. om een zo efficiënt mogelijke afwikkeling van de faillissementsboedels te realiseren. ${ }^{17}$

\section{De WHOA als instrument om}

groepsherstructureringen bij één rechtbank onder te brengen

Bij bestudering van de WHOA vanuit groepsperspectief valt als eerste de bijzondere regeling inzake relatieve bevoegdheid op: de vraag welke Nederlandse rechtbank bevoegd is bij verzoeken in het kader van de akkoordprocedure. Als meerdere groepsvennootschappen tegelijkertijd in het kader van de WHOA een herstructureringsakkoord aanbieden, dan kunnen zij een van de Nederlandse gerechten die relatief bevoegd zijn, in een gezamenlijk verzoek vragen kennis te nemen van alle verzoeken die worden ingediend in het kader van de totstandkoming van een akkoord. ${ }^{18}$ Daarmee wordt onnodige fragmentatie voorkomen; ook als de groepsvennootschappen zich in verschillende arrondissementen bevinden, kunnen alle akkoordprocedures ten aanzien van de verschillende Nederlandse groepsvennootschappen bij één Nederlandse rechtbank worden ondergebracht.

De mogelijkheid om akkoordprocedures bij één Nederlandse rechtbank te centraliseren beperkt zich evenwel niet tot Nederlandse groepen vennootschappen. De WHOA biedt Nederlandse rechters namelijk de mogelijkheid om onder omstandigheden ook herstructureringsakkoorden ten aanzien van 'niet-Nederlandse' schuldenaren te homologeren. Het wetsvoorstel breekt daarmee met de tot op heden in Nederland geldende rechtsmachtsregels voor insolventieprocedures. Faillissementsprocedures en surseances van betaling kunnen slechts in Nederland worden geopend voor zover de schuldenaar 'Nederlands' is ${ }^{19}$ dan wel een vestiging of kantoor in Nederland heeft. ${ }^{20}$

Voor de openbare akkoordprocedure geldt dit uitgangspunt ten aanzien van 'Europese schuldenaren' nog steeds. De WHOA is gestoeld op de gedachte dat de Nederlandse rechter zijn internationale bevoegdheid voor openbare akkoordprocedures toetst aan de hand van de herziene IVO. ${ }^{21}$ De minister wijst daar zelf ook op in de memorie van toelichting bij de WHOA. ${ }^{22}$ De herziene IVO is van toepassing indien het 'cen-

17. Zie bijv. recentelijk het faillissement van de verschillende Intertoysgroepsvennootschappen. Een reden om niet over te gaan tot de benoeming van één of meer dezelfde curatoren is de mogelijke aanwezigheid van tegengestelde belangen tussen de verschillende faillissementsboedels. Gedacht kan bijv. worden aan een casus waarin discussie bestaat omtrent de toelaatbaarheid van intragroeptransacties, omdat deze mogelijk vernietigd kunnen worden met een beroep op de faillissementspauliana.

18. Art. 369 lid 8 ontwerp-Fw.

19. Het centrum van voornaamste belangen (art. 3 lid 1 herziene IVO, zie hieronder) of de zetel (art. 2 Fw jo. art. 1:10 BW) is in Nederland gelegen.

20. Art. 3 lid 2 herziene IVO, respectievelijk art. 2 lid 4 Fw.

21. Art. 369 lid 7 sub a ontwerp-Fw. Zie uitgebreid over de verhouding tussen de herziene IVO en de WHOA P.M. Veder, Internationale aspecten van de WHOA: de openbare en de besloten akkoordprocedure buiten faillissement, FIP 2019, afl. 6, p. 53-62.

22. MvT, p. 32. Zie noot 10 voor de relevante verwijzing. 
trum van voornaamste belangen' (ook wel: de 'COMI') ${ }^{23}$ van de schuldenaar is gelegen binnen de Europese Unie. ${ }^{24} \mathrm{Als}$ de schuldenaar een rechtspersoon is, valt de COMI in veel gevallen samen met de plaats van zijn statutaire zetel. ${ }^{25}$ Is de COMI van de schuldenaar in Nederland gelegen, dan kan de Nederlandse rechter een hoofdprocedure openen. Die openingsbeschikking wordt automatisch erkend in andere EUlidstaten ${ }^{26}$ en heeft daar in beginsel dezelfde gevolgen als in Nederland. ${ }^{27}$ Ook verdere beslissingen van de Nederlandse rechter, zoals beslissingen inzake het verloop en de beëindiging van de insolventieprocedure en homologatiebeslissingen ter zake een akkoord, worden zonder verdere formaliteiten erkend. ${ }^{28}$ Buitenlandse erkenning is bijvoorbeeld gunstig als een van de groepsvennootschappen in een andere EU-lidstaat nog vermogensbestanddelen heeft: een door de Nederlandse rechter afgekondigde afkoelingsperiode ${ }^{29}$ geldt dan in beginsel ook voor die buitenlandse vermogensbestanddelen. ${ }^{30}$ De erkenning van de homologatiebeslissing voorkomt daarnaast bijvoorbeeld dat schuldeisers in een andere EU-lidstaat alsnog verhaal kunnen nemen voor het afgeschreven deel van hun vordering. ${ }^{31}$ Erkenning van de Nederlandse WHOA-beschikkingen kan om dezelfde redenen ook buiten de EU wenselijk of noodzakelijk zijn. Schuldenaren zijn dan aangewezen op eventuele verdragen die voorzien in erkenning, dan wel het commune internationaal privaatrecht van het betreffende land. De mogelijkheid om in een land buiten de EU om erkenning van een Nederlandse insolventieprocedure te verzoeken, zou bijvoorbeeld kunnen bestaan als de betreffende 'derde

23. Art. 3 lid 1 herziene IVO.

24. Overweging 25 bij de herziene IVO. Omdat Denemarken gebruik heeft gemaakt van zijn opt-out-recht ten aanzien van de herziene IVO, is de verordening niet van toepassing ten aanzien van Denemarken, zie overweging 88 bij de herziene IVO.

25. Art. 3 lid 1 herziene IVO. Zie ook HvJ EG 2 mei 2006, C-341/04, ECLI:EU:C:2006:281 (Eurofood IFSC Ltd.).

26. Art. 19 lid 1 herziene IVO.

27. Art. 3 lid 1 jo. art. 20 lid 1 herziene IVO. De herziene IVO kent evenwel ook veel uitzonderingen op dit uitgangspunt. Zie bijv. de mogelijkheid om op grond van art. 3 lid 2 herziene IVO een secundaire procedure te openen en het palet aan uitzonderingen met betrekking tot toepasselijk recht in art. 8-18 herziene IVO.

28. Art. 32 herziene IVO.

29. Art. 376 ontwerp-Fw biedt een uitgebreide regeling die voorziet in een afkoelingsperiode van ten hoogste acht maanden in geval van een akkoordprocedure onder de WHOA.

30. Zie evenwel art. 8 herziene IVO, dat bepaalt dat de opening van een insolventieprocedure de rechten van derden met een zakelijk recht (bijv. een pand- of hypotheekrecht) op goederen van de schuldenaar in een andere lidstaat onverlet laat. Een Nederlandse hoofdprocedure onder de herziene IVO kan dus bijv. niet voorkomen dat een zekerheidsgerechtigde zijn hypotheekrecht ten aanzien van Duitse onroerende zaken van de schuldenaar uitwint.

31. Vgl. in dat kader de Nederlandse commune internationaal privaatrechtelijke regel uit het Vleeschmeesters-arrest, die inhoudt dat de rechtsgevolgen van buitenlandse faillissementen die niet onder de (herziene) IVO vallen toepassing missen in Nederland, indien en voor zover deze erin resulteren dat onvoldane crediteuren zich niet langer kunnen verhalen op - tijdens of na afloop van het faillissement - in Nederland gelegen actief van de failliet. Zie HR 31 mei 1996, ECLI:NL:HR: 1996:ZC2091, NJ 1998/108 (Coppoolse/De Vleeschmeesters), recentelijk herhaald in HR 13 september 2013, ECLI:NL:HR:2013:BZ5668, TvI 2014/6 m.nt. Berkenbosch, r.o. 2.2. staat' de Model Law on Cross-Border Insolvency (1997) (hierna: de Model Law) heeft geïmplementeerd in zijn nationale wetgeving. ${ }^{32}$

De Nederlandse rechter heeft ook rechtsmacht inzake een openbare akkoordprocedure als de COMI van de schuldenaar niet in Nederland is gelegen maar in een andere EU-lidstaat, als de schuldenaar een 'vestiging' heeft in Nederland. ${ }^{33}$ De gevolgen van een dergelijke territoriale of secundaire procedure gelden in beginsel evenwel alleen ten aanzien van de goederen van de schuldenaar die zich in Nederland bevinden. ${ }^{34}$ Schuldeisers die niet met het herstructureringsakkoord hebben ingestemd, kunnen niet worden gehouden aan een beperking van hun rechten (zoals een (gedeeltelijke) schuldkwijtschelding) ten aanzien van goederen in een andere EU-lidstaat dan de EU-lidstaat waar de procedure is geopend. ${ }^{35}$

Bij toepasselijkheid van de herziene IVO kunnen openbare akkoordprocedures dus enkel worden toegepast bij vennootschappen met een structurele aanwezigheid (hun COMI of een vestiging) in Nederland. Tegenover deze beperkte jurisdictieregeling staat de automatische erkenning in andere EU-lidstaten als groot voordeel. Daarnaast voorziet de herziene IVO, zoals hierboven reeds aangehaald, in specifieke bepalingen voor groepsvennootschappen. ${ }^{36}$ Deze bepalingen zijn van toepassing als er in meer dan één EU-lidstaat insolventieprocedures die betrekking hebben op verschillende leden van eenzelfde groep ondernemingen zijn geopend. ${ }^{37}$ Nederlandse of buitenlandse 'insolventiefunctionarissen' (zoals curatoren $)^{38}$ die zijn benoemd in verschillende insolventieprocedures van groepsvennootschappen, de betrokken rechtbanken en in geval van een openbare akkoordprocedure de schuldenaar zelf ${ }^{39}$ kunnen dan bijvoorbeeld verplicht zijn om grensoverschrijdend samen te werken. ${ }^{40}$

Ten aanzien van openbare akkoordprocedures bij schuldenaren met hun COMI buiten de EU en besloten akkoordprocedures geldt een aanzienlijk ruimere rechtsmachtsregeling: het commune Nederlandse internationaal recht voor rechtsmacht bij verzoekschriftprocedures. ${ }^{41}$ Deze procedures vallen

32. Zie https://uncitral.un.org/en/texts/insolvency/modellaw/cross-border _insolvency/status voor een overzicht van staten die de Model Law in hun nationale wetgeving hebben geimplementeerd. De Minister voor Rechtsbescherming kondigde in zijn 'Voortgangsbrief programma herijking faillissementsrecht' van 27 augustus 2019 aan te overwegen om onderdelen uit de Model Law ook in de Fw op te nemen.

33. Art. 3 lid 2 herziene IVO. Zie voor de definitie van 'vestiging' art. 2 lid 10 herziene IVO.

34. Idem.

35. Art. 20 lid 2 herziene IVO.

36. Art. 56-77 herziene IVO.

37. Overweging 62 bij de herziene IVO. Zie art. 2 lid 13 herziene IVO voor de gehanteerde definitie voor 'groep ondernemingen'.

38. Art. 2 lid 5 herziene IVO.

39. Art. 76 herziene IVO.

40. Zie bijv. art. 56-58 herziene IVO.

41. Art. 369 lid 7 ontwerp-Fw. 


\section{Maandblad \\ Ondernemingsrecht}

namelijk buiten de reikwijdte van de herziene IVO. ${ }^{42}$ De WHOA is daarnaast gebaseerd op de veronderstelling dat de Brussel I-bis-verordening betreffende de rechterlijke bevoegdheid, de erkenning en de tenuitvoerlegging van beslissingen in burgerlijke en handelszaken (hierna: Brussel I-bis) ${ }^{43}$ niet van toepassing is op de akkoordprocedures die buiten de reikwijdte van de herziene IVO vallen. ${ }^{44}$

Kort weergegeven is de Nederlandse rechter in dergelijke gevallen bevoegd indien de schuldenaar in Nederland zijn woonplaats of gewone verblijfplaats heeft, of de zaak anderszins 'voldoende met de rechtssfeer van Nederland verbonden is. ${ }^{45}$ Van een dergelijke voldoende verbondenheid is niet alleen sprake als de schuldenaar zijn COMI of een vestiging in Nederland heeft, maar ook bijvoorbeeld als: ${ }^{46}$

a. de schuldenaar (substantiële) activa in Nederland heeft;

b. een (substantieel) deel van de te herstructureren schulden voortvloeit uit verbintenissen waarop Nederlands recht van toepassing is of waarbij een Nederlandse forumkeuze is gemaakt;

c. een (substantieel) deel van de groepsvennootschappen van de schuldenaar in Nederland is gevestigd, waarbij geldt dat wanneer één of meer akkoorden aangeboden zijn ten aanzien van meerdere groepsvennootschappen, het voldoende is dat ten minste één van de schuldenaren zijn 'COMI' of een vestiging in Nederland heeft; ${ }^{47}$ of

d. de schuldenaar aansprakelijk is voor schulden van een andere schuldenaar ten aanzien waarvan de Nederlandse rechter rechtsmacht heeft.

Elk van deze omstandigheden levert op zichzelf al voldoende verband met de Nederlandse rechtssfeer op, aldus de memorie van toelichting. ${ }^{48}$ De Nederlandse rechter is ten aanzien van

42. In geval van openbare procedures ten aanzien van een schuldenaar met zijn COMI buiten de EU is de herziene IVO niet van toepassing, omdát de COMI van die betreffende schuldenaar buiten de EU is gelegen, zie overweging 25 bij de herziene IVO. De herziene IVO is daarnaast niet van toepassing op procedures die niet zijn opgenomen in de limitatieve lijst in bijlage A, zie art. 2 lid 4 en overweging 9 bij de herziene IVO. De besloten akkoordprocedure zal niet ter opname op die lijst worden aangedragen, omdat niet wordt voldaan aan de materiële reikwijdte van de herziene IVO. De opening van een besloten akkoordprocedure wordt namelijk niet openbaar gemaakt, hetgeen wél is vereist volgens de materiele reikwijdtebepaling in art. 1 lid 1 en overweging 12 bij de herziene IVO.

43. Verordening (EU) 1215/2012 betreffende de rechterlijke bevoegdheid, de erkenning en de tenuitvoerlegging van beslissingen in burgerlijke en handelszaken (herschikking).

44. Veder heeft recentelijk uiteengezet waarom beschikkingen in het kader van de besloten akkoordprocedure ook niet op de voet van de Brussel I-bis voor automatische erkenning in andere EU-lidstaten in aanmerking zouden komen. Zie Veder 2019, p. 60-62. Anders: Nijnens, die betoogt dat zowel de openbare als de besloten akkoordprocedure buiten het werkingsgebied van de herziene IVO valt, maar de Brussel I-bis wél van toepassing is, W.J.E. Nijnens, Internationaal privaatrechtelijke aspecten van de WHOA, TvI 2019/32.

45. Art. 369 lid 7 ontwerp-Fw jo. art. 3 Rv. De woonplaats van een rechtspersoon is de plaats van zijn zetel, zie art. 1:10 BW.

46. MvT, p. 32.

47. MvT, voetnoot 36 op p. 32.

48. Idem. openbare akkoordprocedures bij schuldenaren met hun COMI buiten de EU en bij besloten akkoordprocedures dus onder omstandigheden ook bevoegd wanneer de schuldenaar een naar buitenlands recht opgerichte vennootschap betreft die geen aanwezigheid in Nederland heeft. In dergelijke gevallen waarin de herziene IVO niet van toepassing is, lijkt de schuldenaar voor erkenning van de herstructurering binnen en buiten de EU evenwel aangewezen op mogelijke verdragen of het commune internationaal privaatrecht aldaar, zoals implementaties van de Model Law.

Het samenspel tussen openbare en besloten akkoordprocedures biedt multinationale groepen vennootschappen onder omstandigheden de mogelijkheid om hun gehele schuldenlast centraal in Nederland te herstructureren - in het bijzonder omdat de schuldenaar ${ }^{49}$ zelf kan kiezen of hij een openbare of besloten akkoordprocedure initieert. ${ }^{50}$ Dit laat zich goed illustreren aan de hand van de groep uit figuur 1.

Neemt men deze groep als uitgangspunt, dan zou het huidige Nederlandse insolventierecht geen mogelijkheid bieden om de gehele groep met toepassing van Nederlandse wetgeving te herstructureren. De Nederlandse rechter is immers enkel bevoegd om procedures te openen ten aanzien van groepsvennootschappen met hun COMI of vestiging in Nederland. ${ }^{51}$ Ten aanzien van de Nederlandse HoldCo, FinCo en OpCo kunnen Nederlandse insolventieprocedures worden geopend (surseance van betaling, dan wel een faillissementsprocedure). De Portugese OpCo zal in Portugal om opening van een insolventieprocedure moeten verzoeken en de Braziliaanse OpCo in Brazilië.

Onder de WHOA zouden evenwel akkoorden ten aanzien van alle groepsvennootschappen in Nederland kunnen worden gehomologeerd: ten aanzien van de Nederlandse HoldCo, FinCo en OpCo een akkoord uit een openbare akkoordprocedure. Hun COMI zal immers in Nederland gelegen zijn. Ten aanzien van de Portugese en Braziliaanse OpCo zou de Nederlandse rechter een herstructureringsakkoord uit een besloten akkoordprocedure kunnen homologeren, bijvoorbeeld op de grond dat de Nederlandse groepsvennootschappen in Nederland zijn gevestigd (zie voorbeeld c hierboven).

Omdat de COMI's van de Nederlandse HoldCo, FinCo en OpCo in Nederland zullen liggen, werk(t)(en) (de gevolgen van) de herstructurering ten aanzien van deze groepsvennootschappen - zoals een gedeeltelijke schuldvermindering - automatisch door in andere lidstaten. De herstructurering ten aanzien van de Braziliaanse en Portugese OpCo's werken

49. Of de herstructureringsdeskundige, indien benoemd op grond van art. 371 ontwerp-Fw.

50. Art. 369 lid 6 ontwerp-Fw.

51. Of, voor zover de herziene IVO niet van toepassing is: statutaire zetel of kantoor in Nederland, zie art. $2 \mathrm{Fw}$, voor zover het surseance van betaling betreft tevens in verbinding met art. 214 lid $2 \mathrm{Fw}$. 


\section{Maandblad}

Ondernemingsrecht

\section{Figuur 1 Voorbeeld van een multinationale groep}

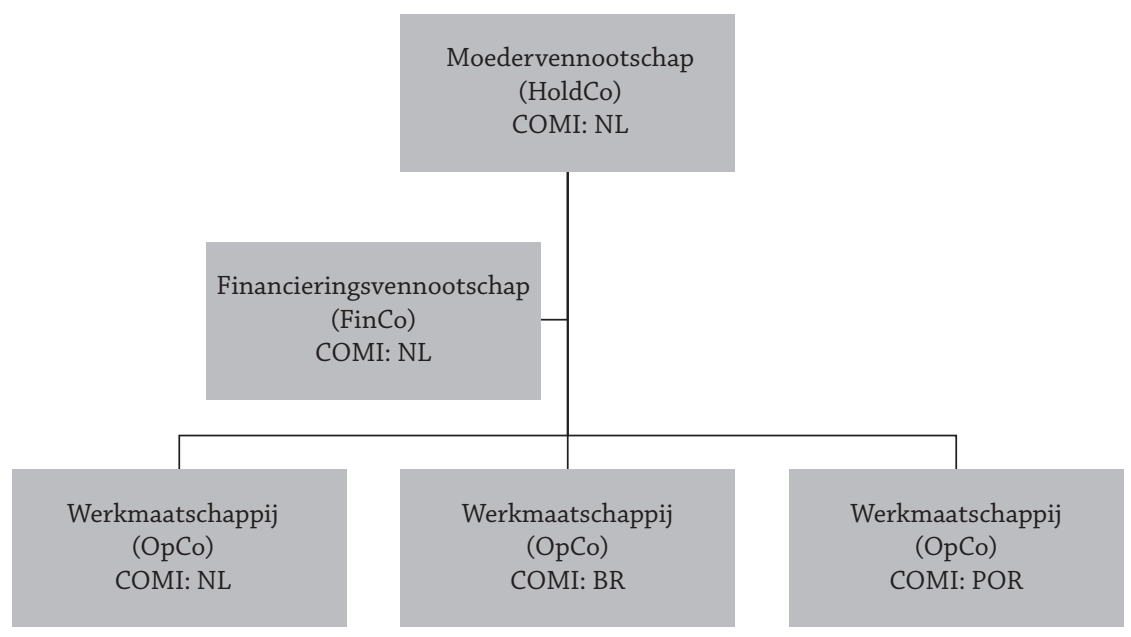

slechts door in het buitenland (waaronder Brazilië en Portugal, waar de respectieve OpCo's normaliter substantiële vermogensbestanddelen zullen hebben) voor zover verdragen of het commune internationaal privaatrecht van dat buitenland daartoe aanleiding geven.

De mogelijkheid om schuldherstructureringen van multinationale groepen in Nederland plaats te laten vinden, geeft de WHOA een aanzienlijke meerwaarde. Het centraliseren van herstructureringen ten aanzien van dergelijke groepen kan namelijk grote voordelen hebben. Als een groep bestaat uit vennootschappen uit verschillende landen, neemt de hierboven aangehaalde desintegratieproblematiek aanzienlijk toe. Zoals aangegeven kunnen rechtbanken in een nationale context vaak pragmatische oplossingen toepassen, zoals de benoeming van één curator in faillissementsprocedures. In internationale context is een dergelijke pragmatische benadering veelal moeilijk, zo niet haast onmogelijk. Dat resulteert in insolventieprocedures ten aanzien van de verschillende groepsvennootschappen in meerdere landen, met meerdere rechtbanken en verschillende procedurele en materiële rechtsregels. Dit leidt tot extra kosten ${ }^{52}$ en mogelijk verlies van de 'synergiewaarde' die veelal is vervat in de groepsonderneming als geheel. Deze fragmentatie maakt het herstructureren van groepen in internationale context vaak tot een grote uitdaging. Zoals Van Galen in 2012 opmerkte: ${ }^{53}$

52. Zo ook de Europese wetgever, zie overweging 7 bij Richtlijn (EU) 2019/1023 van het Europees Parlement en de Raad van 20 juni 2019 betreffende preventieve herstructureringsstelsels, betreffende kwijtschelding van schuld en beroepsverboden, en betreffende maatregelen ter verhoging van de efficiëntie van procedures inzake herstructurering, insolventie en kwijtschelding van schuld, en tot wijziging van Richtlijn (EU) 2017/1132 (Richtlijn betreffende herstructurering en insolventie).

53. R.J. van Galen, Insolvent groups of companies in cross border cases and rescue plans, in: Corporate rescue (preadvies van de Nederlandse Vereniging voor Rechtsvergelijkend en Internationaal Insolventierecht), 2012, digitaal beschikbaar via www.nvrii.nl/uploads/files/NVRII Preadviezen_2012.pdf, p. 52.
'To my knowledge, no plan involving continuation of the business of group companies has ever been accepted in three or more jurisdictions.'

Het centraliseren van insolventieprocedures ten aanzien van multinationale groepen vennootschappen kan evenwel ook minder positieve gevolgen hebben. Zo kunnen schuldeisers van de niet-Nederlandse groepsvennootschappen onverwachts worden geconfronteerd met een ander forum en toepasselijk recht waar(naar) hun vorderingen worden behandeld. Omdat het procedurele en materiële (insolventie)recht per land aanzienlijk kan verschillen, kan dat een wezenlijk effect op de positie van schuldeisers hebben. Vorderingen van een aandeelhouder uit hoofde van een aandeelhouderslening worden naar huidig Nederlands recht bijvoorbeeld veelal geacht concurrent te zijn, ${ }^{54}$ terwijl Duits recht dergelijke vorderingen achterstelt. ${ }^{55}$ Hoewel de WHOA een dergelijke toetsing niet voorschrijft, is het aldus raadzaam dat Nederlandse rechters zich er bij het bepalen van hun rechtsmacht ten aanzien van buitenlandse groepsvennootschappen van vergewissen dat de groep een zodanige eenheid vormt, dat de voordelen van centralisatie opwegen tegen de mogelijke nadelen voor schuldeisers. De open norm van 'voldoende verbondenheid' lijkt daartoe de ruimte te bieden: in gevallen waarin deze belangenafweging negatief uitvalt, kan worden betoogd dat de zaak onvoldoende verbonden is met de Nederlandse rechtssfeer om rechtsmacht van de Nederlandse rechter te dragen.

\section{Herstructureren van groepsgaranties met de WHOA}

De WHOA bevat nog een tweede instrument dat groepsherstructureringen aanzienlijk kan vergemakkelijken: de regeling inzake herstructurering van groepsgaranties.

\footnotetext{
54. Zie bijv. M.J.H. Orval \& M.N. de Groot, De achtergestelde aandeelhouder(slening), FIP 2011, afl. 4, p. 102-105.
}

55. $\$ 39$ Abs. 1 Nr. 5, Abs. 4 en 5 Insolvenzordnung. 


\section{Maandblad \\ Ondernemingsrecht}

Het wetsvoorstel hanteert als uitgangspunt dat een herstructureringsakkoord geen effect heeft op rechten van schuldeisers jegens borgen en medeschuldenaren die aansprakelijk zijn voor een schuld van de schuldenaar die het akkoord aanbiedt (hierna: de hoofdschuldenaar) of op enigerlei wijze zekerheid hebben gesteld voor betaling van die schuld (hierna: garanties). ${ }^{56}$ Schuldeisers behouden ook na homologatie van het akkoord het recht om deze derden aan te spreken tot voldoening van hun oorspronkelijke vorderingen vóór homologatie van het akkoord. ${ }^{57} \mathrm{Als}$ het herstructureringsakkoord bijvoorbeeld inhoudt dat schuldeisers slechts een deel van hun vordering krijgen terugbetaald tegen finale kwijting van die vordering, kunnen schuldeisers zich voor het restant van de oorspronkelijke vordering alsnog wenden tot de borg of medeschuldenaar.

Dergelijke garanties komen binnen groepen vennootschappen veelvuldig voor, bijvoorbeeld in het kader van een groepsfinanciering. Als gevolg van deze - en andere - kruisverbanden tussen groepsvennootschappen slaat financiële problematiek bij één groepsvennootschap in veel gevallen ook over naar de rest van de groep. Juist als de (hoofd)schuldenaar zijn betalingsverplichtingen niet meer na kan komen, zullen schuldeisers in de regel een beroep doen op door groepsvennootschappen afgegeven garanties. Als de garantieverstrekkende groepsvennootschap zelf ook niet in staat is om deze verplichtingen te voldoen, zal hij genoodzaakt zijn om de gang naar de insolventiegriffie te maken: het zogenaamde domino-effect. De WHOA maakt voor groepsgarantie een uitzondering op het uitgangspunt dat een herstructureringsakkoord verplichtingen van derden die zich sterk hebben gemaakt voor de schuldenaar onverlet laat. Artikel 372 ontwerp-Fw vermeldt namelijk:

'Een akkoord als bedoeld in artikel 370, eerste lid, kan ook voorzien in de wijziging van rechten van schuldeisers jegens rechtspersonen die samen met de schuldenaar een groep vormen als bedoeld in artikel $24 \mathrm{~b}$ van Boek 2 van het Burgerlijk Wetboek (...).'

Een herstructureringsakkoord in het kader van de WHOA kan derhalve ook verplichtingen herstructureren van groepsvennootschappen die zich op enigerlei wijze sterk hebben gemaakt voor de schulden van de hoofdschuldenaar, zonder dat ten aanzien van die groepsvennootschappen zélf een procedure hoeft te worden geopend. Het herstructureringsakkoord krijgt dan een breder toepassingsbereik, niet alleen ten aanzien van de schuldenaar die het aanbiedt, maar ook ten aanzien van groepsvennootschappen. Toepassing van deze bepaling vereist dat: ${ }^{58}$

a. de rechten van die schuldeisers jegens de groepsvennootschap strekken tot voldoening of tot zekerheid voor de nakoming van verbintenissen van de hoofdschuldenaar of

56. Art. 370 lid 2 ontwerp-Fw jo. art. $160 \mathrm{Fw}$.

57. MvT, p. 9.

58. Art. 372 lid 1 ontwerp-Fw. van verbintenissen waarvoor die groepsvennootschap met of naast de hoofdschuldenaar aansprakelijk is;

b. de groepsvennootschap - evenals de hoofdschuldenaar in een toestand verkeert waarin het redelijkerwijs aannemelijk is dat zij met het betalen van haar schulden niet zal kunnen voortgaan;

c. de betrokken groepsvennootschap zelf heeft ingestemd met de voorgestelde wijziging, of - als dat niet zo is het akkoord wordt aangeboden door een herstructureringsdeskundige; 59

d. de rechtbank rechtsmacht (internationale jurisdictie) heeft als de groepsvennootschap zelf een herstructureringsakkoord op grond van de WHOA zou aanbieden en een verzoek tot homologatie zou indienen; en

e. de betreffende groepsvennootschap niet reeds zelf een herstructureringsakkoord ten aanzien van deze verplichtingen heeft aangeboden. ${ }^{60}$

Deze regeling biedt dus uitkomst bij groepsvennootschappen waarbij de financiële problematiek hoofdzakelijk wordt veroorzaakt door afgegeven groepsgaranties en die met de enkele herstructurering van deze groepsgaranties weer een houdbaar schuldenprofiel hebben. Een herstructurering van de gehele schuldenlast of een groter gedeelte daarvan kan dan achterwege blijven. Daarbij kan bijvoorbeeld worden gedacht aan een moedermaatschappij die garanties heeft afgegeven in het kader van een obligatie-uitgifte door het financieringsvehikel van de groep.

De mogelijkheid om groepsgaranties met een breed akkoord te herstructureren kan onder omstandigheden ook worden toegepast voor garanties die zijn afgegeven door buitenlandse groepsvennootschappen. Artikel 372 ontwerp-Fw vereist dat de Nederlandse rechter rechtsmacht zou hebben als de betreffende groepsvennootschap zélf een akkoord zou aanbieden en homologatie zou verzoeken. ${ }^{61}$ De Nederlandse rechter kan zoals besproken onder de WHOA ook rechtsmacht hebben ten aanzien van vennootschappen zonder structurele aanwezigheid in Nederland, voor zover de herziene IVO buiten toepassing blijft. ${ }^{62}$ Volgens de memorie van toelichting is de enkele omstandigheid dat de buitenlandse groepsvennootschap zich sterk heeft gemaakt voor de schulden van een hoofdschuldenaar ten aanzien waarvan de Nederlandse rechter rechtsmacht heeft, al voldoende voor de Nederlandse rechter om zichzelf ook bevoegd te verklaren om een breed akkoord te homologeren dat mede ziet op groepsgaranties afgegeven door die buitenlandse groepsvennootschap. ${ }^{63}$ Ook

59. De 'herstructureringsdeskundige' is een onafhankelijke partij die op verzoek van iedere schuldeiser, aandeelhouder of de krachtens wettelijke bepalingen bij de door de schuldenaar gedreven onderneming ingestelde ondernemingsraad of personeelsvertegenwoordiging door de rechtbank kan worden benoemd om in plaats van de schuldenaar een akkoord voor te bereiden en aan te bieden. Zie art. 371 ontwerp-Fw.

60. MvT, p. 42.

61. Art. 372 lid 1 onder d ontwerp-Fw.

62. Zie par. 3 .

63. MvT, p. 32. Zie par. 3 . 
is voldoende dat, wanneer één of meer herstructureringsakkoorden ten aanzien van meerdere groepsvennootschappen worden aangeboden, één van die groepsvennootschappen haar COMI of een vestiging in Nederland heeft. ${ }^{64}$ De Nederlandse rechter zal dus snel rechtsmacht aan kunnen nemen om artikel 372 ontwerp-Fw ook ten aanzien van niet-Nederlandse groepsvennootschappen toe te passen, als de herziene IVO niet van toepassing is. Of een dergelijk internationaal breed akkoord de rechten van de schuldeisers vanwege de groepsgaranties in het buitenland ook effectief aantast, hangt af van de mogelijkheden tot erkenning van het akkoord ten aanzien van de buitenlandse groepsvennootschap onder mogelijke verdragen of het commune internationaal privaatrecht aldaar.

In gevallen waarin de herziene IVO van toepassing is, zal het toepassingsbereik van artikel 372 ontwerp-Fw aanzienlijk beperkter zijn. Zoals aangegeven is deze verordening van toepassing op openbare akkoordprocedures bij schuldenaren wier COMI in de EU is gelegen. ${ }^{65}$ De herziene IVO gaat uit van een enkelvoudige benadering, waarbij nationale rechters rechtsmacht moeten hebben ten aanzien van iedere schuldenaar die zij tot object van een insolventieprocedure maken. ${ }^{66}$ De Nederlandse rechter mag artikel 372 ontwerp-Fw bij toepasselijkheid van de herziene IVO dus enkel toepassen bij garantieverstrekkende groepsvennootschappen wier COMI in Nederland is gelegen, of bij een vennootschap met een vestiging in Nederland. ${ }^{67}$ In het eerste geval genieten de homologatiebeschikking en eventuele samenhangende beschikkingen automatische erkenning in de EU. In het geval van een Nederlandse vestiging zullen de effecten van die beschikkingen in beginsel zijn beperkt tot goederen in Nederland. Tegenstemmende of niet-stemmende schuldeisers kunnen dan alsnog voor hun oorspronkelijke vordering verhaal halen op goederen die in andere EU-lidstaten zijn gelegen.

Zoals Veder en Van Hees ten aanzien van het vorige ontwerp voor de WHOA reeds opmerkten, herbergt de herziene IVO daarnaast een aanzienlijke beperking voor de toepassing van artikel 372 ontwerp-Fw (destijds art. 370 lid 2 ontwerp-Fw) bij groepsvennootschappen met een vestiging in Nederland en hun COMI in een andere EU-lidstaat. ${ }^{68}$ Artikel 3 lid 4 herziene IVO schrijft voor dat, voor zover er niet reeds een insolventieprocedure is geopend in de EU-lidstaat waar de COMI van die schuldenaar is gelegen, er geen insolventieprocedure in de EU-lidstaat van vestiging (een zogenaamde territoriale procedure) kan worden geopend, tenzij, kort gezegd: ${ }^{69}$

64. Idem.

65. Zie par. 3.

66. Zie onder meer HvJ EU 15 december 2011, C-191/10, ECLI:EU:C: 2011:838, JOR 2012/93 m.nt. P.M. Veder (Rastelli), r.o. 13-29.

67. Art. 3 lid 1 en 2 herziene IVO. Zo ook P.M. Veder \& J.J. van Hees, Internationale aspecten van het dwangakkoord ter voorkoming van faillissement, in: Het dwangakkoord buiten faillissement (preadvies van de Vereeniging 'Handelsrecht' 2017), Zutphen: Uitgeverij Paris 2017, p. 201.

68. Veder \& Van Hees 2017, p. 201.

69. Art. 3 lid 4 herziene IVO. a. de opening van een hoofdinsolventieprocedure in de EUlidstaat waar de schuldenaar zijn COMI heeft niet mogelijk is; of

b. de territoriale procedure wordt aangevraagd door een plaatselijke schuldeiser of een overheidsinstantie.

De regeling inzake groepsgaranties heeft juist tot doel om een separate procedure ten aanzien van de garantieverstrekkende groepsvennootschap te voorkomen. Bij grensoverschrijdende toepassing van artikel 372 ontwerp-Fw zal ten aanzien van groepsvennootschappen met een vestiging in Nederland dus normaliter geen insolventieprocedure zijn geopend in de EUlidstaat waar hun COMI zich bevindt. Als de garantieverstrekkende groepsvennootschap een vestiging in Nederland heeft en haar COMI dus in een andere EU-lidstaat is gelegen, kan de Nederlandse rechter artikel 372 ontwerp-Fw enkel op deze groepsvennootschap toepassen voor zover aan één van beide vereisten is voldaan, hetgeen vaak niet het geval zal zijn.

\section{Conclusie}

De huidige Nederlandse Fw kent tot op heden geen specifieke bepalingen inzake insolvente groepen vennootschappen. Dergelijke insolventieprocedures kunnen bij geïntegreerde groepsondernemingen leiden tot desintegratie en waardeverlies, door een veelvoud aan procedures voor de verschillende groepsvennootschappen en in voorkomende gevallen bij verschillende rechtbanken en met verschillende curatoren. Bij multinationale groepen neemt deze desintegratieproblematiek aanzienlijk toe: insolventieprocedures ten aanzien van de groepsvennootschappen in verschillende landen, met verschillende rechtbanken en verschillende procedurele en materiële rechtsregels. Het herstructureren van groepen is vanwege deze fragmentatie vaak een grote uitdaging.

Bij implementatie van de WHOA zal de Fw voor het eerst sinds haar totstandkoming bepalingen inzake groepsvennootschappen bevatten. Het wetsvoorstel biedt verschillende groepsinstrumenten in nationale en internationale context. Zo wordt gepoogd het domino-effect van insolventie binnen groepen vennootschappen tegen te gaan door groepsgaranties op efficiënte wijze met een breed akkoord te herstructureren. De WHOA biedt daarnaast de mogelijkheid om groepsherstructureringen te centraliseren voor één rechtbank, zowel in nationale als in internationale context. Beide instrumenten zullen zonder twijfel een waardevolle toevoeging aan het Nederlands faillissementsrecht zijn.

Hoe deze instrumenten toe- en inpassing zullen vinden in het internationale insolventierecht is vooralsnog niet geheel te overzien. Zo verhoudt grensoverschrijdende toepassing van het brede herstructureringsakkoord zich moeilijk met de herziene IVO. Toepassing van de akkoordprocedure ten aanzien van 'niet-Nederlandse' groepsvennootschappen vereist daarnaast een gang buiten de herziene IVO om, waardoor dergelijke herstructureringsakkoorden het voordeel van automatische erkenning onder de herziene IVO ontberen. Het is 


\section{Maandblad}

Ondernemingsrecht

onzeker of, en zo ja: in hoeverre, dergelijke herstructureringsakkoorden in het buitenland zullen worden erkend.

Het moge evenwel duidelijk zijn dat het Nederlands insolventierecht bij inwerkingtreding van de WHOA en het brede, flexibele toepassingsbereik daarvan een grote moderniseringsslag maakt op het gebied van groepsinsolventies.

Met de WHOA introduceert de wetgever een nieuw instrument in de Fw: het dwangakkoord buiten surseance en faillissement. De WHOA biedt verschillende mogelijkheden om insolventie bij groepen vennootschappen tegen te gaan, zowel in nationale als in internationale context. 